\title{
Effect of Temperature on $\mathrm{N}_{2} \mathrm{O}$ and NO Emission in a Partial Nitrification SBR Treating Reject Wastewater
}

\author{
Z. Bao ${ }^{1,2}$, S. Midulla ${ }^{1,3}$, A. Ribera-Guarida ${ }^{1}$, G. Mannina ${ }^{3}$, \\ D. $\operatorname{Sun}^{2}$, and M. Pijuan ${ }^{1(\bowtie)}$ \\ ${ }^{1}$ Catalan Institute for Water Research (ICRA), \\ Scientific and Technological Park of the University of Girona, Girona, Spain \\ ${ }^{2}$ Beijing Key Lab for Source Control Technology of Water Pollution, \\ Beijing Forestry University, Beijing, China \\ 3 Dipartimento di Ingegneria Civile, Ambientale, \\ Aerospaziale, dei Materiali, Università di Palermo, \\ Viale delle Scienze, Ed. 8, 90128 Palermo, Italy
}

\begin{abstract}
Temperature is a very important parameter during nitritation, having a direct effect on ammonia oxidation rate (AOR) and enzymatic activities which relate to both $\mathrm{N}_{2} \mathrm{O}$ and $\mathrm{NO}$ emission. This study aims at investigating the effect of temperature on $\mathrm{AOR}, \mathrm{N}_{2} \mathrm{O}$ and $\mathrm{NO}$ production in an enriched ammonia oxidizing bacteria (AOB) sequencing batch reactor (SBR) performing partial nitrification (PN) of synthetic reject wastewater. To achieve that, a SBR was subject to several shifts in temperature (in the range of 30 to $15{ }^{\circ} \mathrm{C}, 5{ }^{\circ} \mathrm{C}$ for each decrease). Cycle studies, which contain two aeration phases, were conducted under each temperature. The results showed that AOR specific exponentially correlates with the temperature during the temperature decreasing experiments. With the decrease of the temperature, $\mathrm{N}_{2} \mathrm{O}$ firstly increased and then dropped to very low levels along with the decrease of the AOR, unlike NO that did not show any apparent connection with the temperature.
\end{abstract}

Keywords: Ammonia oxidation rate $\cdot$ Nitrous oxide $\cdot$ Nitric oxide $\cdot$ Reject wastewater $\cdot$ Temperature

\section{Introduction}

Nitrous oxide $\left(\mathrm{N}_{2} \mathrm{O}\right)$, a potent greenhouse gas, can be produced during biological removal of nitrogen through the processes of nitrification and denitrification (Mannina et al. 2016; Foley et al. 2010; Kampschreur et al. 2009). Also, Nitric Oxide (NO) can be produced during these processes, and although it has received less attention by the research community, it is a detrimental gas toxic for many microorganisms and also involved in the depletion of the ozone layer (Rodríguez-Caballero and Pijuan 2013). Nitrification occurs during aerobic conditions and therefore $\mathrm{N}_{2} \mathrm{O}$ and NO production during this process is of special concern since the gases produced are directly emitted. The production of $\mathrm{N}_{2} \mathrm{O}$ and $\mathrm{NO}$ during nitrification occurs during the conversion of ammonia to nitrite, a process called PN or nitritation which is conducted by AOB. This 
process is becoming more attractive for wastewater treatment plants due to its aeration savings and is widely implemented for reject wastewater treatment and lately also for domestic wastewater treatment.

$\mathrm{N}_{2} \mathrm{O}$ and $\mathrm{NO}$ are produced through two different pathways during nitrification: (i) the hydroxylamine $\left(\mathrm{NH}_{2} \mathrm{OH}\right)$ oxidation pathway, and (ii) the nitrifier denitrification pathway. There have been several studies reporting the factors affecting $\mathrm{N}_{2} \mathrm{O}$ production in enriched AOB cultures. The effect of $\mathrm{pH}$ (Law et al. 2011), DO (Pijuan et al. 2014) and both DO and $\mathrm{NO}_{2}{ }^{-}$(Peng et al. 2015) have been explored and linked to $\mathrm{N}_{2} \mathrm{O}$ production. On the other hand, less information is available regarding the combined behaviour of $\mathrm{N}_{2} \mathrm{O}$ and $\mathrm{NO}$ under different conditions. $\mathrm{N}_{2} \mathrm{O}$ and $\mathrm{NO}$ emissions were studied in the same reactor enriched with AOB bacteria (Rodríguez-Caballero and Pijuan 2013). These authors found that SBR cycle configurations reducing $\mathrm{N}_{2} \mathrm{O}$ emissions resulted in an increase of NO, highlighting the importance of monitoring both gases simultaneously. Also, the relationships between the ammonia oxidation rate and the $\mathrm{NO}$ and $\mathrm{N}_{2} \mathrm{O}$ production rates have been reported, being linear (Stüven and Bock 2001) and exponential (Law et al. 2012), respectively.

Temperature is a very important parameter during nitritation having a direct effect on ammonia oxidation rate (AOR) (Guo et al. 2010, Kim et al. 2008) and enzymatic activities (i.e. NirK and NoR), which can be related to $\mathrm{N}_{2} \mathrm{O}$ and $\mathrm{NO}$ emission. Nevertheless, little is known about the effect that temperature shifts have on these emissions during partial nitrification.

This study aims at investigating the effect of temperature on AOR, $\mathrm{N}_{2} \mathrm{O}$ and $\mathrm{NO}$ production in an enriched AOB sequencing batch reactor (SBR) performing partial nitrification of synthetic reject wastewater. To achieve that, an SBR was subject to several shifts in temperature (in the range of 30 to $15^{\circ} \mathrm{C}$ ), and cycle studies were conducted under each temperature.

\section{Methods and Materials}

A cylindrical SBR with a working volume of $8 \mathrm{~L}$ treating synthetic reject wastewater was used for this study. Before starting the experiments the temperature in the reactor was controlled at $30{ }^{\circ} \mathrm{C}$, mimicking the temperature conditions of reactors treating reject wastewater. The cycle configuration consisted in: feed-1 (1'15"), aeration-1 (105'), feed-2 (1'15'), aeration-2 (103'), purge (2') settling (132'30') and decanting (15'). $1 \mathrm{~L}$ of synthetic reject wastewater $\left(\mathrm{NH}_{4} \mathrm{HCO}_{3}, 1 \mathrm{~g} \mathrm{NH}_{4}{ }^{+}-\mathrm{N} / \mathrm{L}\right)$ was added into the reactor during each feeding phase resulting in a hydraulic retention time (HRT) of $24 \mathrm{~h}$. DO was controlled within the range of 1.5-2.0 $\mathrm{mg} \mathrm{O}_{2} / \mathrm{L}$ and $\mathrm{pH}$ was only controlled when reaching values below 7.0 by adding $\mathrm{NaHCO}_{3} 1 \mathrm{M}$. At the time of the study, the SBR had been under stable operation for more than 2 years, with $98 \%$ conversion of $\mathrm{NH}_{4}{ }^{+}$to $\mathrm{NO}_{2}{ }^{-}$and no $\mathrm{NO}_{3}{ }^{-}$detected in the effluent. The percentage of AOBs analysed by FISH was around $80 \%$ of the total bacterial population.

The effect of temperature shifts on $\mathrm{N}_{2} \mathrm{O}$ and $\mathrm{NO}$ emissions was assessed in the same SBR. Four different temperatures were tested: $30{ }^{\circ} \mathrm{C}$ (normal temperature of the reactor), $25{ }^{\circ} \mathrm{C}, 20{ }^{\circ} \mathrm{C}$ and $15{ }^{\circ} \mathrm{C}$. The reactor was operated for 1 week under each temperature 


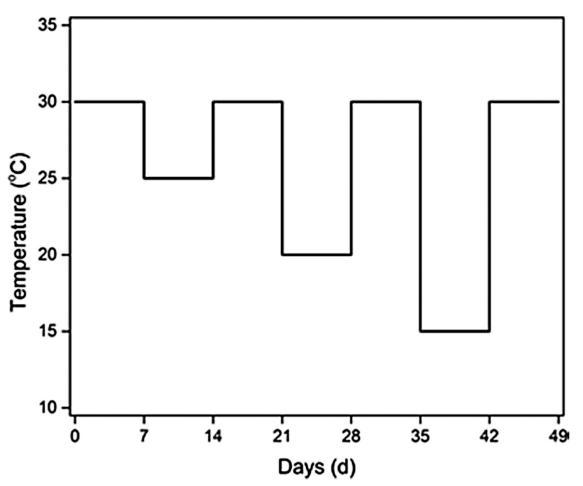

Fig. 1. Schematic representation of the changes of temperature applied in the reactor.

and then it was returned to $30{ }^{\circ} \mathrm{C}$ for another week before changing the temperature again. A schematic representation of the experimental approach is presented in Fig. 1.

Two cycle studies were conducted under each temperature with samples for $\mathrm{NH}_{4}{ }^{+}$, $\mathrm{NO}_{2}{ }^{-}$and $\mathrm{NO}_{3}{ }^{-}$being taken at the first $10 \mathrm{~min}$, as well as the half and the end of each aeration phases. Online off-gas measurements of $\mathrm{N}_{2} \mathrm{O}$ and $\mathrm{NO}$ emissions were carried out with commercially available online gas analysers (Servomex 4900 and ECO physics CLD60, respectively).

The equations used to calculate $\mathrm{N}_{2} \mathrm{O}$ (Eq. 1), $\mathrm{NO}$ (Eq. 2) and AOR (Eq. 3) are detailed below. $\mathrm{AOR}_{\mathrm{sp}}$ was calculated as the slope of the straight line interpolating the concentration of ammonia found in the reactor, the time and the concentration of the biomass.

$$
\begin{gathered}
N_{2} O=\sum_{t=15}^{t} C_{N_{2} O} \times Q_{\text {gas }} \times t \\
N O=\sum_{t=15}^{t} C_{N O} \times Q_{\text {gas }} \times t \\
A O R_{s p}=\frac{d C_{N_{4}^{+}-\text {consumed }}}{d t \times M L V S S}
\end{gathered}
$$

Where the $C_{\mathrm{N}_{2} \mathrm{O}}$ and $C_{\mathrm{NO}}$ are

$C_{N_{2} O}\left(\mathrm{~g} \mathrm{~N}_{2} \mathrm{O}-\mathrm{N} / \mathrm{L}\right)=C_{N_{2} O}(\mathrm{ppmv}) * 10^{-6} * \mathrm{~N}_{2} \mathrm{O}$ molar volume $\left(0.0423\right.$ at $15{ }^{\circ} \mathrm{C}$, 0.0416 at $20{ }^{\circ} \mathrm{C}, 0.0409$ at $25^{\circ} \mathrm{C}, 0.0402$ at $\left.30{ }^{\circ} \mathrm{C}\right) * 28$.

$\mathrm{C}_{\mathrm{NO}}\left(\mathrm{g} \mathrm{N}_{2} \mathrm{O}-\mathrm{N} / \mathrm{L}\right)=\mathrm{C}_{\mathrm{NO}}(\mathrm{ppmv})^{*} 10^{-6} * \mathrm{NO}$ molar volume (same as the $\mathrm{N}_{2} \mathrm{O}$ molar volume) *14.

$\mathrm{t}$ is the time (min) and $\mathrm{Q}_{\mathrm{gas}}$ is the aeration rate $(\mathrm{L} / \mathrm{min})$. 


\section{Results and Discussion}

\subsection{PN-SBR Performance}

The biomass was able to oxidise all the ammonium to nitrite when operating at $30{ }^{\circ} \mathrm{C}$ and $25{ }^{\circ} \mathrm{C}$. However, some accumulation of ammonium was observed at the end of aeration 2 during $20{ }^{\circ} \mathrm{C}$ and $15^{\circ} \mathrm{C}$ due to the low AOR. This is because the ammonia oxidation rate was affected by the temperature and decreased when temperature decreased. Figure 2 shows the effect of temperature on ammonia oxidation rate in the SBR. The relationship between specific AOR and temperature has been found to be exponential (Fig. 2), similar to some previous studies (Guo et al. 2010). In any of the temperatures, the concentrations of nitrate were negligible in the effluent which indicated that the partial nitrification performance of the system was not disturbed.

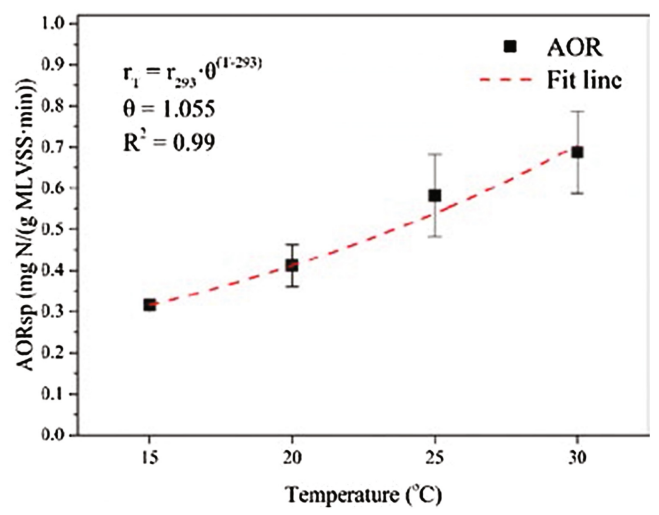

Fig. 2. Specific AOR at different temperatures.

\section{2 $\quad \mathrm{N}_{2} \mathrm{O}$ and NO Emissions}

Both $\mathrm{N}_{2} \mathrm{O}$ (Fig. 3a) and NO (Fig. 3b) were emitted during the two aeration phases. In the first aeration, a big $\mathrm{N}_{2} \mathrm{O}$ peak was detected and attributed to the stripping of $\mathrm{N}_{2} \mathrm{O}$ produced during settling (Rodríguez-Caballero and Pijuan 2013). A second peak of $\mathrm{N}_{2} \mathrm{O}$ was found at the beginning of feed-2, being much lower than the first one. During the rest of the aeration periods, the emissions were very low and remained constant. The behavior of $\mathrm{NO}$ was different from the one of $\mathrm{N}_{2} \mathrm{O}$. No peak was observed at the beginning of the cycle and its profile was very similar between both aeration phases (as shown in Fig. 3b).

$\mathrm{N}_{2} \mathrm{O}$ and $\mathrm{NO}$ emissions were calculated using data from the whole cycle, excluding the data from the first $15 \mathrm{~min}$ (in order to eliminate the $\mathrm{N}_{2} \mathrm{O}$ and $\mathrm{NO}$ produced during the settling) and only calculating the emissions during the second aerobic phase (including feed-2 period) (Fig. 4). In the case of $\mathrm{N}_{2} \mathrm{O}$, the majority of emissions were obtained during the first $15 \mathrm{~min}$ and attributed to the $\mathrm{N}_{2} \mathrm{O}$ produced during settling. Similar emissions were observed in the temperature range from 30 to $20{ }^{\circ} \mathrm{C}$, 

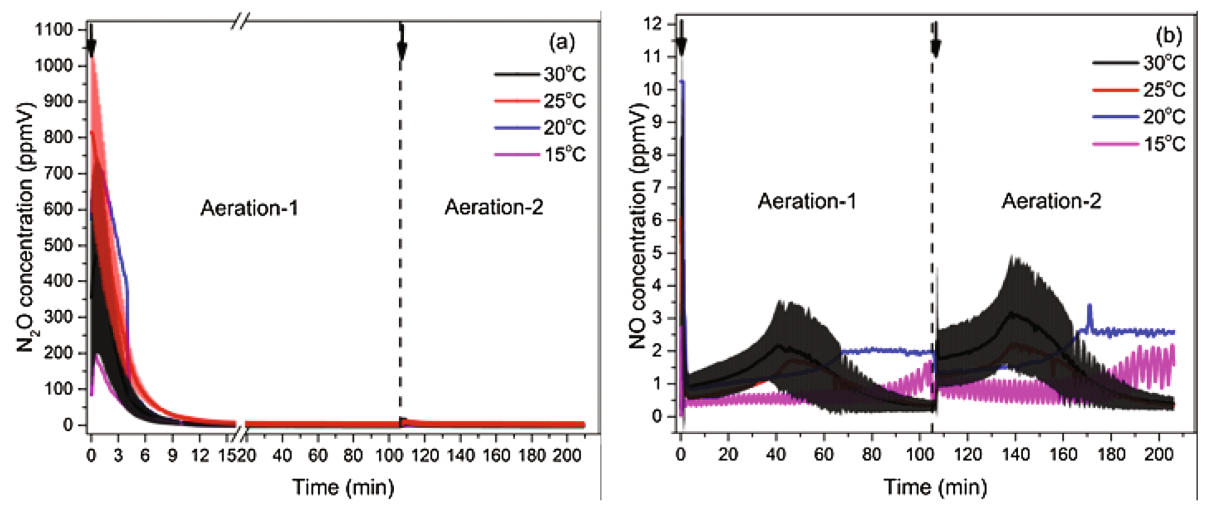

Fig. 3. $\mathrm{N}_{2} \mathrm{O}$ and $\mathrm{NO}$ emission patterns at different temperatures (Arrows represent the feeding period).
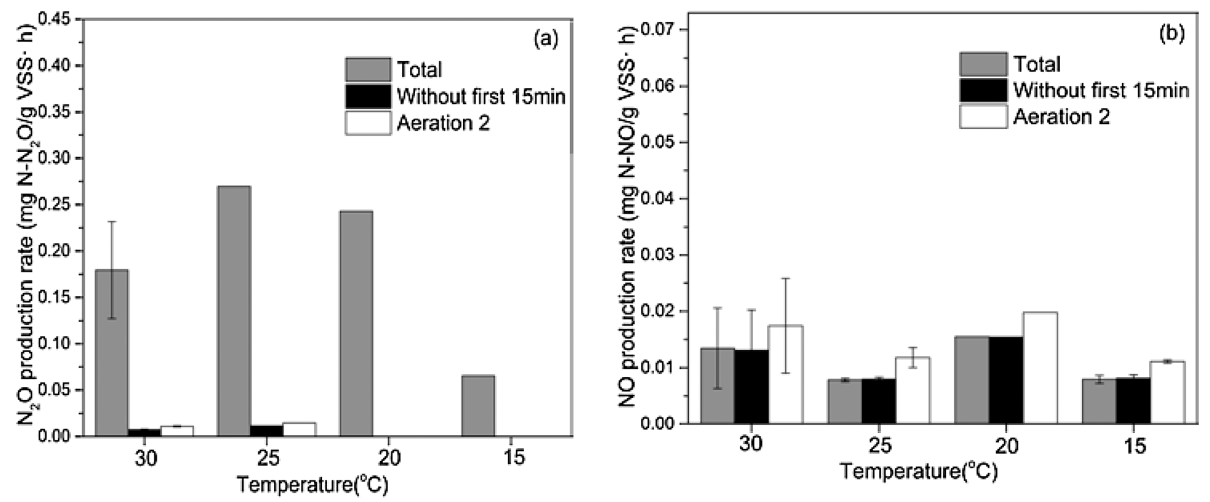

Fig. 4. $\mathrm{N}_{2} \mathrm{O}$ and $\mathrm{NO}$ production rate with and without cut of the first peak

decreasing when the reactor was operating at $15^{\circ} \mathrm{C}$. Also interesting is the fact that no $\mathrm{N}_{2} \mathrm{O}$ emissions were detected under 20 and $15^{\circ} \mathrm{C}$ apart for those ones coming from the settling. In the case of $\mathrm{NO}$ emissions, these ones occurred along all the aeration phases, being the emissions from the second aeration always higher. No correlation was found with the temperature.

The $\mathrm{N}_{2} \mathrm{O}$ and $\mathrm{NO}$ emission rates and ratios were calculated subtracting the first 15 min of aeration at different temperatures (Table 1). $\mathrm{N}_{2} \mathrm{O}$ production rate firstly increased when decreasing the temperature to $25{ }^{\circ} \mathrm{C}$ and then decreased with the decrease of the temperature. However, no apparent connection was found between NO and temperature, being the NO emissions of the same order of magnitude as the $\mathrm{N}_{2} \mathrm{O}$ emissions. 
Table 1. $\mathrm{N}_{2} \mathrm{O}$ and $\mathrm{NO}$ emission rates and ratios at different temperatures

\begin{tabular}{l|l|l|l|l}
\hline Temperature & \multicolumn{2}{|l|}{$\mathrm{N}_{2} \mathrm{O}$ production rate } & \multicolumn{2}{l}{ NO production rate } \\
\hline$\left({ }^{\circ} \mathrm{C}\right)$ & $(\mathrm{mg}$ N/g VSS$\cdot \mathrm{h})$ & $\left(\mathrm{N}-\mathrm{N}_{2} \mathrm{O} / \mathrm{N}_{-} \mathrm{NH}_{4}^{+}\right) \%$ & $(\mathrm{mg}$ N/g VSS·h $)$ & $\left(\mathrm{N}-\mathrm{NO} / \mathrm{N}-\mathrm{NH}_{4}{ }^{+}\right) \%$ \\
\hline 30 & 0.007 & $0.018 \%$ & 0.015 & $0.037 \%$ \\
\hline 25 & 0.011 & $0.033 \%$ & 0.008 & $0.029 \%$ \\
\hline 20 & 0.000 & $0.000 \%$ & 0.018 & $0.072 \%$ \\
\hline 15 & 0.000 & $0.000 \%$ & 0.010 & $0.051 \%$ \\
\hline
\end{tabular}

\section{Conclusions}

- $\mathrm{AOR}_{\mathrm{sp}}$ exponentially correlates with the temperature during the temperature decreasing experiments.

- With the decrease of the temperature, $\mathrm{N}_{2} \mathrm{O}$ firstly increased and then dropped to very low levels along with the decrease of the AOR, unlike NO that did not show any apparent connection with the temperature.

Acknowledgements. This study was funded by project CTM2015-66892-R (from the Spanish Government Ministerio de Economía y Competitividad and FEDER funds).

\section{References}

Foley J, De Haas D, Yuan Z, Lant P (2010) Nitrous oxide generation in full-scale biological nutrient removal wastewater treatment plants. Water Res 44(3):831-844

Guo J, Peng Y, Huang H, Wang S, Ge S, Zhang J, Wang Z (2010) Short-and long-term effects of temperature on partial nitrification in a sequencing batch reactor treating domestic wastewater. J Hazard Mater 179(1):471-479

Kampschreur MJ, Temmink H, Kleerebezem R, Jetten MS, van Loosdrecht MC (2009) Nitrous oxide emission during wastewater treatment. Water Res 43(17):4093-4103

Kim J-H, Guo X, Park H-S (2008) Comparison study of the effects of temperature and free ammonia concentration on nitrification and nitrite accumulation. Process Biochem 43(2):154160

Law Y, Lant $\mathrm{P}$, Yuan Z (2011) The effect of $\mathrm{pH}$ on $\mathrm{N}_{2} \mathrm{O}$ production under aerobic conditions in a partial nitritation system. Water Res 45(18):5934-5944

Law Y, Ni B-J, Lant P, Yuan Z (2012) $\mathrm{N}_{2} \mathrm{O}$ production rate of an enriched ammonia-oxidising bacteria culture exponentially correlates to its ammonia oxidation rate. Water Res 46 (10):3409-3419

Mannina G, Ekama G, Caniani D, Cosenza A, Esposito G, Gori R, Garrido-Baserba M, Rosso D, Olsson G (2016) Greenhouse gases from wastewater treatment - a review of modelling tools. Scie Tot Env 551:254-270

Peng L, Ni B-J, Ye L, Yuan Z (2015) The combined effect of dissolved oxygen and nitrite on $\mathrm{N}_{2} \mathrm{O}$ production by ammonia oxidizing bacteria in an enriched nitrifying sludge. Water Res 73:29-36 
Pijuan M, Tora J, Rodríguez-Caballero A, César E, Carrera J, Pérez J (2014) Effect of process parameters and operational mode on nitrous oxide emissions from a nitritation reactor treating reject wastewater. Water Res 49:23-33

Rodríguez-Caballero A, Pijuan M (2013) $\mathrm{N}_{2} \mathrm{O}$ and $\mathrm{NO}$ emissions from a partial nitrification sequencing batch reactor: exploring dynamics, sources and minimization mechanisms. Water Res 47(9):3131-3140

Stüven R, Bock E (2001) Nitrification and denitrification as a source for $\mathrm{NO}$ and $\mathrm{NO}_{2}$ production in high-strength wastewater. Water Res 35(8):1905-1914 